„Bohemistyka” 2019, nr 2, ISSN 1642-9893

Jana VLČKOVÁ-MEJVALDOVÁ

Stanislav ŠTĚPÁNÍK

Univerzita Karlova v Praze

\section{Percepce výslovnostních chyb učiteli českého jazyka"}

Keywords: Czech language, didactics, orthoepy, phonetics, phonetic aspects, pronunciation, pronunciation error, teacher's subject matter knowledge

Klíčová slova: český jazyk, didaktika, ortoepie, fonetika, učitelova znalost obsahu, výslovnost, výslovnostní chyba, zvuková stránka

\section{Abstract}

Pronunciation is one of the basic characteristics of one's speech culture. L1 teaching should lead to the development of speaking skills, whose part is also mastering the orthoepic norm. One of the preconditions of that is the teachers' subject matter knowledge, their own practically mastery of Czech orthoepy. The paper brings the results of a study conducted with a sample of 148 teachers from Czech primary and lower- and upper-secondary schools which researched the teachers' ability to detect pronunciation errors in a segment of continuous speech. The results indicate that the awareness of the orthoepic norm among Czech language teachers is rather insufficient, and that there is quite strong correlation between the teachers' knowledge of the orthoepic norm and the pronunciation errors their pupils make.

Dobrá výslovnost je jedním ze základních rysů řečové kultivovanosti mluvčího. Vyučování mateřskému jazyku by mělo vést $\mathrm{k}$ rozvoji řečových dovedností, jejichž součástí je zvládnutí ortoepické normy. Jednou z podmínek tohoto procesu je sama učitelova znalost a praktické ovládání české ortoepie. Článek přináší výsledky studie, jíž se zúčastnilo 148 učitelů na 1.,2. a 3. vzdělávacím stupni. Studie zjištovala schopnost učitelů detekovat výslovnostní chyby v souvislé promluvě. Výsledky naznačují, že povědomí o české ortoepické normě je mezi učiteli spíše nedostačující a že může existovat souvislost mezi učitelovou znalostí ortoepické normy a kvalitou mluveného projevu žáka.

* Příspěvek vznikl v rámci projektu PRIMUS/HUM/19 Didaktika českého jazyka v současném vzdělávacím kontextu, podpořeného Univerzitou Karlovou a Pedagogickou fakultou Univerzity Karlovy. Autoři děkují za poskytnutou podporu.

\section{Požadavek řečové kultury v historii a dnes}

Stížnosti na nízkou úroveň kultury mluveného projevu se v odborné i laické veřejnosti objevují od nepaměti. Již Jan Blahoslav ve třetí knize spisu Vady kazateli̊v klade požadavek toho, co bychom dnes označili jako hlasová hygiena, a neméně pozornosti věnuje nešvarům jako nepřiměřená síla hlasu nebo nepřiměřené tempo. Jeho kritice neušly ani parazitní zvuky, které se objevují v projevech sledovaných mluvčích, v Blahoslavově př́ípadě kazatelů. Velmi inspirativní je Blahoslavův požadavek přizpůsobení formální stránky projevu komunikační situaci, zejména posluchačům, a komunikační intenci. Pokud jde o vlastní výslovnost, začíná kapitolu De vitiis při tom, což v sobě sdružuje pronunciatio slovy: „Zlé a šeredné pronunciatí žádného není konce" (Čejka 2013, s. 188).

B. Hála v čl. III, $§ 4$ Zatímního statusu ${ }^{1}$ (viz též Dvořáčková 2014 , s. 57; Vlčková-Mejvaldová 2019) zamýšleného Fonetického ústavu, který měl vzniknout v rámci Ústavu pro jazyk český ČSAV, v roce 1950 formuluje jako jeden ze základních úkolů pozvednutí hlasové a mluvní kultury. I přes množství titulů, které se zabývají rétorikou, mluveným projevem a komunikací a jež neustále upozorňují na nutnost péče o mluvený projev (např. Krobotová 2000; Kraus 2010; Hájková 2011; Šmajsová Buchtová 2005; Hoffmannová a kol. 2016, ad.), výzkumy řady autorů ukazují, že neuspokojivý stav v této oblasti je stále aktuální (srov. např. Čmejrková, Hoffmannová 2011; Daneš 2009; Kuldanová 2001; Macoun, Dvořáková 2008; či Palková 2005, 2008-2009, 2017-2018).

Četné doklady také ukazují, že nedostatky v mluveném projevu se nevyhýbají ani učitelům českého jazyka (Balkó 2007-2008; Svobodová 2003, či Málková 2012, 2014-2015; viz dále). Úloha učitele mateřštiny jako mluvního vzoru je přitom pro rozvoj mluveného projevu žáka zcela zásadní, zvláště pak na 1. stupni ZŠ (srov. např. Brab-

${ }^{1}$ Zatimni status Fonetického ústavu. Zpráva přípravné komise pro zřizení Ústavu pro záznam, výzkum a kulturu hlasu i mluvy (dále stručně: Ústavu fonetického). 30.4.1950. sig. 341, inv. č. 482, karton 233, 1950, MUA AV ČR. 
cová a kol. 1990; Čechová, Styblík 1998, či Browne 2007). „Rozhodujícím činitelem při této činnosti [tj. osvojování spisovné výslovnosti - pozn. aut.] musí být učitel, nebot' na jeho dokonalé dikci závisí úspěšné splnění tohoto závažného úkolu" (Brabcová a kol. 1990, s. 86).

Osvojovat si mluvní a komunikační dovednosti v dospělosti může být oproti školnímu věku na jednu stranu snazší, protože rozhodne-li se dospělý mluvčí své komunikační dovednosti zlepšit, zpravidla ví, proč je potřeba být komunikačně a mluvně obratný, tuší (či za pomoci odborníka zjišt’uje), v čem jsou jeho slabiny, a tudíž je silněji vnitřně motivován. Na druhou stranu jsou jeho mluvní návyky již dlouhodobě fixované, a proto práce na odstranění špatných návyků může být dlouhodobější a náročnější. Základní předpoklad pro nápravu nedobrého stavu však je, že si mluvčí své rezervy uvědomuje, což, jak ukazují výzkumy, nemusí být prrípad ani profesionálních mluvčích - srov. např. přiléhavý výrok Z. Palkové (2008-2009, s. 19), že v oblasti kultury mluveného projevu jsme občas svědky ,až demonstrativní vulgarizace standardních hodnot" (k témuž srov. také např. Lollok 2018).

Stejně jako všechny dovednosti, i komunikační a mluvní kultura se snáze a lépe osvojuje v raném věku (srov. Průcha 2011), což je základní východisko pro rozvoj mluveného projevu ve výuce na základní i střední škole - ostatně výstupy v oblasti zvukové stránky jazyka patř́i k obsahu kurikula předmětu český jazyk tradičně (pro historický vhled srov. Šmejkalová 2010, nebo Vlčková-Mejvaldová, Sojka 2016, pro současný stav srov. obsah Rámcového vzdélávacího programu pro základni vzdělávání, Rámcového vzdělávacího programu pro gymnázia i rámcových vzdělávacích programů pro různé obory středního odborného vzdělávání). Péče o správnou výslovnost a vhodné mluvní návyky je v raném stádiu školní výuky zcela nezbytná zvláště ve světle faktu, že počet jedinců v péči českých logopedických pracovišst' se rok od roku zvyšuje (ÚZIS 2014).

Jako metodu ve školní výuce lze samozřejmě uplatňovat, důsledně nebo namátkově, mluvní a řečnická cvičení (srov. Čechová 1985, 1998; Čechová, Styblík 1998), lze implicitně i explicitně vést žáky a studenty k osvojení a aplikaci korektního vyjadřování na různých úrovních. Realisticky je ovšem třeba přiznat, že mluvní a řečnická cvičení jsou z časových či jiných důvodů mnohdy do vyučování zařazována jen zřídka (Štěpáník, Vlčková-Mejvaldová 2019). V takové situaci se velmi silně uplatňuje role mluvních vzorů, kterou přirozeně zastává nejčastěji učitel mateřského jazyka, nositel př́mé, prvotní a nejpřirozenější jazykové (a tedy i řečové) kultury. Jeho role je stěžejní nejen pro vytváření výukových situací pro rozvoj mluveného projevu a mluvení obecně, ale také pro opravu chyb a poskytování zpětné vazby žákům $\mathrm{k}$ jejich projevům. Jak píše v doposud nepřekonaném Profilu češtináře V. Šmilauer (1968-1969), češtinář má být vyzrálá a didakticky i oborově zdatná osobnost. Z tohoto hlediska je znalost fenoménů, které se kultury mluveného slova týkají, zcela nezbytná. Vzhledem ke konstatovanému je namístě položit si základní otázku: Nakolik jsme za zanedbání péče o kulturu mluveného slova jakožto učitelé, nebo dokonce jakožto učitelé učitelů sami zodpovědní?

Výsledky výzkumů jsou v tomto směru nedobré. Balkó (2005-2006) poukazuje na několikero nedostatků $\mathrm{v}$ řeči učitelů: jejich přílišnou mluvní aktivitu, nenáležitou prozodii řeči, rychlé tempo, nedodržování zásad ortoepické normy, parazitující výrazy apod. Málková (2012, 2014-2015) výsledky Balkó potvrzuje a dále upozorňuje na výrazný vliv obecné češtiny na mluvený projev učitelů a ukazuje, že jazykové kompetence češtinářo̊ nejsou výrazně lepší než učitelů jiných předmětů (Málková 2012, s. 108). Př́lišnou mluvní aktivitu učitelů potvrzují i Švaříček, Šed'ová a Šalamounová (2012) či Mareš a Křivohlavý (1995). V jiné studii Balkó (2007-2008, s. 18) konstatuje, že i když učitelé mají dostatek odborných znalostí, postrádají dovednosti řečnické. Poukaz na nedocenění významu nejen praktických dovedností, ale i teoretických znalostí v oblasti zvukové stránky jazyka u učitelů pak najdeme v řadě dalších studií (srov. Balkó 2012-2013; Vlčková-Mejvaldová, Sojka, 2016; Štěpáník, Vlčková-Mejvaldová 2019). Z uvedených dokladů vyplývá, že učitelé češtiny možná v oblasti zvukové stránky jazyka do pedagogické praxe vstupují jak nedostatečně odborně vzděláni, tak i nedůsledně prakticky připraveni; doklady uka- 
zují, že ačkoliv jsou výstupy RVP pro základní a střední vzdělávání formulovány komunikačně, učitelé jsou připravováni spíše teoreticky (srov. Vlčková-Mejvaldová, Sojka 2016). Důsledkem pak bývá fakt, že výuka zvukové stránky jazyka je upozad'ována, příp. zcela opomíjena (srov. Balkó 2012-2013; Bořek-Dohalská a kol. 2016; Kraus 1996-1997; Štěpánová 2013; Vlčková-Mejvaldová, Štěpáník 2017-2018), anebo rezignuje na komunikační pojetí a je i na nižších stupních vzdělávání vedena spíše oborově a teoreticky (to se týká především 3. stupně - srov. Štěpáník, Vlčková-Mejvaldová 2019). Adekvátní zvuková realizace mluveného projevu je přitom zásadní z hlediska sociálního, komunikačního, didaktického i estetického, má zásadní vliv na správné porozumění projevu a komunikační účinek na adresáta (srov. Štěpáník, Vlčková-Mejvaldová 2019).

\section{Rétorika a poučení o zvukové stránce jazyka v př́ípravě učitelů}

Praktická znalost české výslovnostní normy, tedy ortoepických pravidel, je předpokladem schopnosti učitelů reagovat na nestandardní změny hlásek $\mathrm{v}$ řečovém kontinuu, intonační průběhy či distribuci přízvukủ a korigovat je. Lze oprávněně předpokládat, že této znalosti mohli (budoucí) učitelé nabýt nejpozději v rámci své profesní př́ípravy, tedy během učitelského studia. Je proto namístě zde připomenout, $\mathrm{v}$ jaké formě a míře zahrnují různé vysoké školy připravující učitele českého jazyka (potažmo učitele prvního stupně) př́pravu v oblast zvukové stránky češtiny. Zmíněným tématem se detailně zabývá studie Vlčkové-Mejvaldové a Sojky (2016). Z jejich zjištění vyplývá, že budoucím učitelům se poučení o zvukové stránce jazyka a o výslovnostní normě alespoň teoreticky dostává: fonetika a fonologie češtiny je součástí oborového studia na všech fakultách připravujících učitele v České republice, a to hned v prvním, max. ve druhém semestru. Těžištěm poučení o zvukové stránce jazyka je pro budoucí učitele prvního stupně právě výslovnostní norma. Studenti oboru český jazyk a literatura, tedy budoucí učitelé druhého a třetího stupně, jsou ovšem školeni spíše v oborových znalostech (Vlčková-Mejvaldová, Sojka
2016, s. 55-56, 62-63) a nejsou vedeni k dovednosti nahlížet zvukové vlastnosti češtiny v perspektivě budoucí pedagogické aktivity, která by měla naplňovat požadavky definované rámcovými vzdělávacími programy pro jednotlivé stupně školy. Absence této činnosti stejně jako absence propojování jednotlivých jazykových rovin může $\mathrm{v}$ budoucí učitelské praxi stát za rezignací na reflexi kvality zvukové stránky jazyka.

Jak ovšem upozorňují Vlčková-Mejvaldová a Sojka (2016) či Balkó (2012-2013), možnosti učitelské př́ípravy směrem k rozvoji fonetického myšlení budoucích češtinářù a jejich přemýšlení o zvukové stavbě jazyka a o jeho zvucích jsou značně limitované. Vzhledem ke zcela minimální didaktizaci obsahu předmětů zabývajících se zvukovou stránkou jazyka a absenci poukazu na využitelnost nabývaných poznatků v praxi výuky mateřštiny zůstává otázkou, jak s nabytými znalostmi a dovednostmi absolventi učitelských programů zacházejí po svém nástupu do pedagogické praxe, nakolik je pro ně kultura mluveného projevu zásadní a jakou vyvíjejí námahu směrem k výchově a vzdělávání žáků v této oblasti.

Cílem naší studie je zjistit schopnost učitelů českého jazyka na různých stupních škol identifikovat odchylku od normativní ${ }^{2}$, tedy ortoepické, české výslovnosti. Zabýváme se tedy učitelovou znalostí obsahu (srov. Mareš a kol. 1996; Janík 2009), konkrétně ortoepické normy (Hůrková 1995). Hovoříme o jedné z podstatných komponent kompetencí učitele (Vašutová 2007), jež mají zásadní vliv na podobu výuky a její výsledky. Vysoce organizovaná a propracovaná znalostní základna činí učitele expertem (srov. Píšová a kol. 2013, s. 18).

\section{Ortoepie}

Ortoepie je chápána jako stabilizovaný soubor výslovnostních zásad (Hůrková 1995, s. 17), tedy pravidel, která jsou považována za

\footnotetext{
${ }^{2}$ Jsme si vědomi rozdílu ve významu mezi slovy noremni a normativní, nicméně se přidržujeme odborného úzu (srov. např. Hůrková 1995, Suchánková 1992, Čermák 2015).
} 
závazná, zejména v projevech, které se vyznačují určitým stupněm formálnosti a veřejnosti (Palková 1994, s. 321).

Poslední kodifikační př́ručkou české výslovnosti je Výslovnost spisovné češtiny I a II (Hála 1967; Romportl a kol. 1978). Kodifikační status nese rovněž Slovník spisovného jazyka českého, a to po stránce pravopisné, výslovnostní i gramatické. Slovník ovšem vznikal v letech 1960 až 1971, v roce 1989 vyšlo jeho nezměněné druhé vydání. Zmíněné publikace jsou vzhledem $\mathrm{k}$ době svého vzniku poněkud zastaralé - pokud ne obsahem, pak strukturací a celkovým pojetím. Proto za publikaci se závaznou platností je považována Česká výslovnostní norma J. Hůrkové (1995). Sama o sobě kodifikační platnost nemá, ale z Hálovy kodifikační př́ručky vychází a přiměřeným způsobem reflektuje pozdější vývoj. Zároveň ve shodě s názorem Jazykové poradny Ustavu pro jazyk český AV ČR ${ }^{3}$ ji lze na základě její prestiže za kodifikační považovat.

Výslovnostní chybou může být deformace kvality či změna fonologické kvantity vokálu, elize intervokalického konsonantu, zjednodušení souhláskové skupiny, dále změna konsonantu, nejčastěji na základě asimilace znělosti (před jedinečnou souhláskou), místa artikulace nebo způsobu artikulace ad. Na prozodické rovině může dojít k nestandardnímu umístění přízvuku (nejčastěji v předložkovém spojení), dále se může vyskytnout nenormativní intonace zejména ve finálních melodémech interogativních výpovědí (Hůrková 1995, s. 46).

V našem výzkumu vycházíme z ustanovení České výslovnostnínormy (Hůrková 1995), veškeré naše úvahy a závěry jsou proto vztaženy právě k této príručce.

\section{Cíl výzkumu a metodologie}

Cílem výzkumu, jehož výsledky prezentujeme v této studii, je zjistit, do jaké míry jsou učitelé na různých stupních škol schopni identifikovat výslovnostní chyby a jaké faktory - pokud nějaké - tuto jejich dovednost ovlivňují.

\footnotetext{
${ }^{3}$ Http://ujc.avcr.cz/jazykova-poradna/dotazy/0131.html; cit. 4.12.2017.
}

\subsection{Výzkumný vzorek}

Hlavní výzkumnou metodou v naší studii jsou percepční testy s pomocí audionahrávky. Ty proběhly od dubna do června 2017 v Praze, Brně a Olomouci. Nahrávku jsme pustili v rámci vzdělávacích seminářů pro učitele celkem šesti skupinám respondentů, respondenti do dotazníků připojených $\mathrm{k}$ percepčním testům poskytovali informaci o regionu svého působiště a o vzdělávacím stupni, na němž působí. Ve všech skupinách byli zastoupeni učitelé všech vzdělávacích stupňů. Percepčních testů se zúčastnilo celkem 148 učitelů -56 učitelů 1. stupně, 66 učitelů 2 . stupně a 26 učitelů 3 . stupně. Konkrétní údaje jsou obsaženy v tabulce $1 \mathrm{a}$ a $1 \mathrm{~b}$ (tabulky $1 \mathrm{a}$ a $1 \mathrm{~b}$ použity též in Štěpáník, Vlčková-Mejvaldová 2019), z níž vyplývá, že vzorek byl tvořen zkušenými praktiky (Šimoník 1994, Podlahová 2004).

Tab. 1a. Počty respondentů

\begin{tabular}{|l|c|c|c|c||}
\hline & 1. stupeň Ž & 2. stupeň ŽS & 3. stupeň & Celkem \\
\hline Praha & 32 & 30 & 11 & 73 \\
\hline Olomouc & 21 & 25 & 6 & 52 \\
\hline Brno & 3 & 11 & 9 & 23 \\
\hline Celkem & $\mathbf{5 6}$ & $\mathbf{6 6}$ & $\mathbf{2 6}$ & $\mathbf{1 4 8}$ \\
\hline
\end{tabular}

Tab. 1b. Délka jejich pedagogické praxe

\begin{tabular}{||c|c|c|c||}
\hline $\begin{array}{c}\text { Délka pedagogické } \\
\text { praxe (v letech) }\end{array}$ & 1. stupeň ŽS & 2. stupeň ZŠ & 3. stupeň \\
\hline průměr & 16,5 & 17 & 22,7 \\
\hline minimum & 1 & 1 & 3 \\
\hline Q1 & 9 & 7 & 20 \\
\hline median & 17 & 17 & 25 \\
\hline Q3 & 22,5 & 26 & 30 \\
\hline maximum & 39 & 40 & 33 \\
\hline
\end{tabular}


Všechny percepční testy se uskutečnily v prostředí školních učeben, technické vybavení při reprodukci nahrávky bylo identické. Akustické podmínky percepčních testů byly srovnatelné.

\subsection{Zvukový materiál}

Nejen pro účely předkládaného výzkumu vznikl soubor nahrávek, koncipovaných s didaktickým záměrem: $\mathrm{v}$ nahrávkách byly záměrně realizovány předem stanovené odchylky od výslovnostní normy, přičemž na jiných rovinách se jednalo o projevy zcela spisovné (Štěpáník, Vlčková-Mejvaldová 2018). Posluchači se tak mohli zaměřit pouze na zvukovou stránku projevu. Předpokládáme, že v komunikátech, které jsou na ostatních rovinách spisovné a v souladu s jazykovou kodifikací, se výslovnostní chyby projeví jako percepčně významnější (srov. Krčmová 2009, s. 12). Pro výzkum jsme zvolili nahrávku textu Reportáž obsahující různé typy výslovnostních odchylek:

Nedávno jsem viděla film o lidových písních. Jméno už si nepamatuju. Paní v tom filmu povídala hlavně o roce osmnáct set v Evropě. Podle mě není hezčí reportáž, a to už jsem viděla reportáže o př́rodě i o kultuře. $V$ tom filmu byly i děti tančící v krojích Bylo vidět, jak si ten tanec uživají a mají z něho radost. Úplně nejvíc se mi líbilo, když tam nějací chlapi přes šedesát zpívali o pivu. Jeden z nich byl dokonce bezzubý. Ještě si vzpomínám, že tam pak byly asi čtrnáctileté slečny, které stály v okně a zpívaly. Bylo to prostě hezké.

Text namluvila profesionální mluvčí z Českého rozhlasu s více než dvacetiletou rozhlasovou praxí, v oblasti techniky a kultury mluveného projevu odborně a systematicky školená, která byla schopná přesně vyslovit požadovanou podobu jednotlivých problematických míst textu. Nahrávka trvala 35 vteřin a obsahovala 11 různých typů odchylek od výslovnostní normy v 28 následujících výrazech:

- zk r a c ová n í v o k ál ů: [paňí $]^{4}$ - [paňi], [neňí] - [neňi];

${ }^{4}$ Pro transkripci používáme běžnou transkripci češtiny dle Krčmové (2012-2018). Pro odlišení otevřené výslovnosti vokálů zavádíme znaky [1], [ع] a [o].
- o t e vř e né v o kály: [film] - [film], [lidovíx] - [lıdovíx], [si] $[\mathrm{s} 1],[$ bili $]-\left[\mathrm{b}_{11}\right]^{5}$, [slečni] - [slečn1], [spívali] - [spíval1], [bilo][bilo];

- redukce vo kálu: [prost'e] - [prəst'e];

- a b s e n c e povi nné ho rázu: [f?evropje] - [vevropje], [flokňe] - [vokňe];

- elize intervokalického konsonantu: [povídala] [poídala], [?opivu] - [?opiu];

- zjednodušení výslovnosti dvou stejných souh 1 á s e k: [bezzubí] - [bezubí] ${ }^{6}$;

- z j e dno du še ní s o uhlá s kových s kupin: [?ušsi] - [?usi], [?osmnáctset] - [?osmnácet], [nejvícse] - [nejvíce], [gdiš $]-$ [diš $]$, [přnesšedesát] - [přnešedesát], [fspomínám] - [spomínám] ${ }^{7},[$ které] [keré];

- elize iniciálního [j]: [jméno] - [méno], [ješt'e]-[?ešt'e];

- chybná asimilace místa artikulace: [hesčí] - [heščí];

- dis imilace způsobu artikulace: [čtrnáct'ileté] - [štrnást'ileté];

-s l a b i č ná r e d u k c e: [ňejací] - [ňácí], [?úplňe] - [?úpe].

\subsection{Výzkumný postup}

Nahrávku vyslechli respondenti celkem dvakrát.

\footnotetext{
${ }^{5}$ Zvuková realizace tohoto tvaru se $\mathrm{v}$ nahrávce vyskytuje dvakrát, $\mathrm{v}$ rámci analýzy jsme ji však počítali vždy pouze jednou.

${ }^{6}$ Ačkoliv Palková (1994, s. 327) považuje tuto formu za přijatelnou, držíme se ustanovení ortoepické normy dle Hůrkové (1995, s. 32), kde se požaduje výslovnost plná.

${ }^{7}$ Hála (1967, s. 63) v tomto výrazu zjednodušení připouští, protože se zde nevytváŕí sémantická opozice $v z / z$, jak je tomu např́iklad ve výrazech vzmáhat/zmáhat, u nichž Hála požaduje plnou výslovnost. Vzhledem k tomu, že je naše hodnocení ortoepické akceptability založeno na Hůrkové České ortoepické normě (1995), klasifikujeme redukovanou výslovnost iniciální souhláskové skupiny [spomínám] jako chybnou - Hưrková zjednodušení v tomto typu nepřipouští (s. 35n.).
} 
1) Nejprve bylo jejich úkolem zaznamenat do prripravených archů všechna slova, v nichž si všimli jakékoliv výslovnostní chyby.

2) Při druhém poslechu byla respondentům poskytnuta opora v podobě písemného přepisu nahrávky ve standardní ortografické podobě. Úkol respondentů tentokrát byl označit slova, v nichž došlo k odchylce od ortoepické výslovnosti.

Po druhé nahrávce se respondenti k první části již nevraceli. Při obou posleších měli po ukončení záznamu konkretizovat, o jakou chybu šlo. Takto formulovaný úkol předpokládá tři typy kompetencí:

1) Schopnost diferenciace jednotlivých jazykových rovin. Vzhledem ke zcela konkrétnímu požadavku vyhledat odchylky od výslovnostní normy jsme předpokládali, že respondenti nebudou věnovat pozornost chybám, resp. domnělým chybám, na morfologické nebo lexikální úrovni.

2) Znalost ortoepické normy. Schopnost určit chyby pochopitelně předpokládá povědomí o tom, jaká je správná ortoepická podoba daného výrazu.

3) Postřeh a schopnost zachytit zvukový detail ve zvukovém kontinuu promluvy neboli „trénované ucho”. Tuto kompetenci řadíme záměrně na třetí místo, nebot' je bezpředmětná při absenci dvou kompetencí předchozích. $Z$ hlediska školní výuky je však zásadní. Zároveň předpokládá, že respondent je zvyklý všímat si jednotlivostí na úrovni fonetické roviny promluvy.

Formuláře s výsledky byly následně shromážděny a získaná data byla zpracována v programu Excel a podrobena kvantitativní i kvalitativní analýze - $\mathrm{k}$ použitým statistickým metodám srov. dále.

\section{Výsledky výzkumu}

Výsledky percepčních testů nabízí hned několik typů informací: - o percepční závažnosti jednotlivých typů odchylek od ortoepické normy nebo různých př́padů jednoho typu,

- o kompetencích učitelů v oblasti zvukové stránky řeči,
- o některých faktorech, které mohou tyto kompetence ovlivňovat (např. region působiště či stupeň, na němž učitel působí).

Různé chyby byly seskupeny podle typu, přičemž jednotlivé typy odchylek od ortoepické normy nebyly zastoupeny rovnoměrně, ale tak, jak se v textu prrirozeně vyskytly. $V$ grafu 1 jsou seřazeny jednotlivé typy odchylek od ortoepické normy podle procenta detekce respondenty během percepčních testů.

Procenta detekce jednotlivých typů odchylek od ortoepické normy

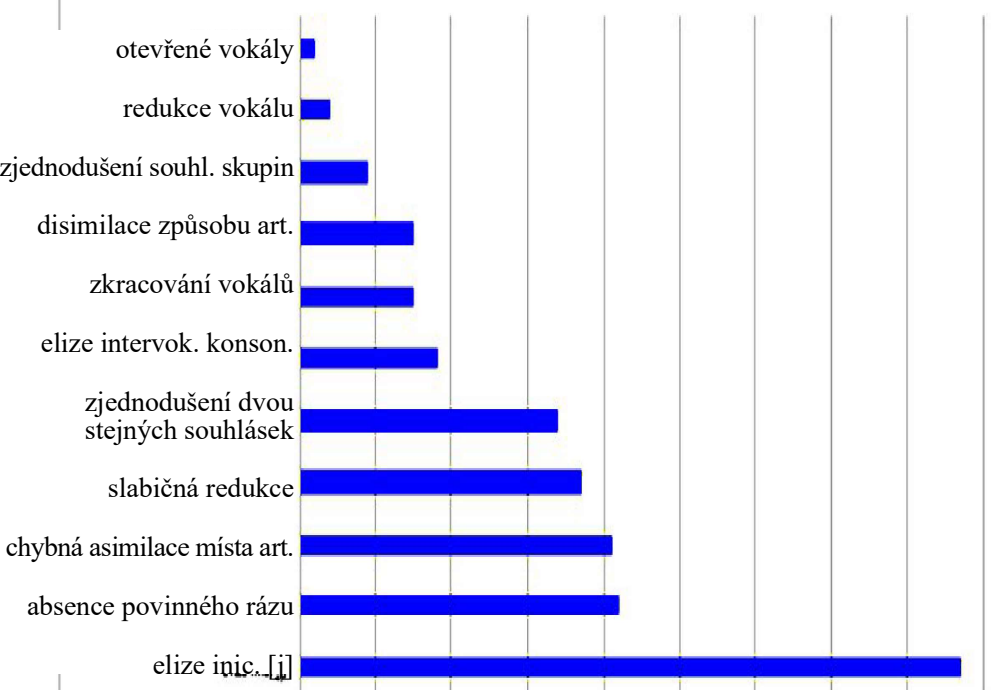

$\begin{array}{lllllllllll}0 \% & 10 \% & 20 \% & 30 \% & 40 \% & 50 \% & 60 \% & 70 \% & 80 \% & 90 \% & 1\end{array}$

Nízké procento detekce u některých typů odchylek (zejména u otevřenosti vokálů nebo u redukce souhláskových skupin) je dáno tím, že některé reprezentace dané odchylky nebyly detekovány vůbec, měly tedy nulové procento identifikace (konkrétní př́iklady viz tabulka 2). 
Tab. 2. Procento správné identifikace různých chybně realizovaných výrazů $\mathrm{v}$ rámci jednotlivých typů ortoepických chyb

\begin{tabular}{|c|c|c|c|c|}
\hline Typ ortoepické chyby & Výraz & $\begin{array}{r}\begin{array}{r}\text { Procenta } \\
\text { detekce }\end{array} \\
\text {. }\end{array}$ & $\begin{array}{c}\text { Pořadí } \\
\text { v identifikaci } \\
\text { chyby }\end{array}$ & $\begin{array}{c}\text { Průměrná } \\
\text { procenta } \\
\text { detekce } \\
\text { za celou } \\
\text { kategorii }\end{array}$ \\
\hline \multirow{2}{*}{ Zkracování vokálů } & [paňi] & 30,3 & 7. & \multirow{2}{*}{15} \\
\hline & [neňi] & 1,4 & 22.-23. & \\
\hline \multirow{7}{*}{ Otevřené vokály } & {$[$ film] } & 5,5 & 16.-17. & \multirow{7}{*}{2} \\
\hline & [11dovíx] & 5,5 & 16. -17. & \\
\hline & {$[\mathrm{s} 1]$} & 0,0 & 24. -28. & \\
\hline & {$\left[\mathrm{b}_{1} \mathrm{l}_{1}\right]$} & 2,8 & 19. & \\
\hline & [slečn1] & 0,0 & 24. -28. & \\
\hline & [spívalı] & 0,0 & 24. -28. & \\
\hline & {$\left[b_{1} b\right]$} & 0,0 & 24. -28. & \\
\hline Redukce vokálu & [prəst'e] & 4,0 & 18. & 4 \\
\hline \multirow{2}{*}{$\begin{array}{l}\text { Absence povinného } \\
\text { rázu }\end{array}$} & [vevropje] & 23,4 & 10. & \multirow{2}{*}{42} \\
\hline & [vokňe] & 60,7 & 3. & \\
\hline \multirow{2}{*}{$\begin{array}{l}\text { Elize intervokalického } \\
\text { konsonantu }\end{array}$} & [poídala] & 29,6 & 9. & \multirow{2}{*}{18} \\
\hline & [?opiu] & 6,2 & 15. & \\
\hline $\begin{array}{l}\text { Zjednodušení } \\
\text { výslovnosti dvou } \\
\text { stejných souhlásek }\end{array}$ & [bezubí] & 33,8 & 6. & 34 \\
\hline \multirow{7}{*}{$\begin{array}{l}\text { Zjednodušení } \\
\text { souhláskových skupin }\end{array}$} & [?usi] & 1,4 & 22.-23. & \multirow{7}{*}{9} \\
\hline & [?osmnácet] & 29,6 & 8. & \\
\hline & [nejvíce] & 2,1 & 20. & \\
\hline & [diš] & 2,0 & 21. & \\
\hline & [přñešedesát] & 15,2 & 11.-12. & \\
\hline & [spomínám] & 13,1 & 13.-14. & \\
\hline & [keré] & 0,0 & 24. -28. & \\
\hline \multirow{2}{*}{ Elize iniciálního [j] } & [méno] & 90 & 1. & \multirow{2}{*}{87} \\
\hline & [?ešt'e] & 81,4 & 2. & \\
\hline $\begin{array}{l}\text { Chybná asimilace místa } \\
\text { artikulace }\end{array}$ & [heščí] & 40,7 & 5. & 41 \\
\hline
\end{tabular}

\begin{tabular}{||l|l|c|c|c||}
\hline \hline $\begin{array}{l}\text { Disimilace způsobu } \\
\text { artikulace }\end{array}$ & [štrnástileté] & 15,2 & $11 .-12$. & \multirow{2}{*}{15} \\
\hline \multirow{2}{*}{ Slabičná redukce } & [ňácí] & 57,2 & 4. & \multirow{2}{*}{37} \\
\cline { 2 - 4 } & [?úpe] & 13,1 & $13 .-14$. & \\
\hline
\end{tabular}

Tabulka 2 podrobně představuje procento správné identifikace různých chybně realizovaných výrazů v rámci jednotlivých typů ortoepických chyb. Údaje jsou souhrnné pro všechny skupiny a vztahují se pro poslech bez opory psaného textu.

Z uvedených údajů vyplývá, že v rámci jednoho typu ortoepické chyby mají různé chybně vyslovené výrazy odlišnou percepční závažnost.

\subsection{Percepční závažnost různých výslovnostních chyb}

Pojem percepční závažnost definujeme jako schopnost chyby vázat na sebe pozornost posluchače a narušit stylistickou homogenitu mluveného projevu, který je na jiných jazykových rovinách (zejména morfologické) spisovný. Pro zakotvení pojmu percepční závažnost můžeme využít Kučerova principu hierarchie (Kučera 1955), který inherentně obsahuje předpoklad dále upřesněný Hronkem (1972, s. 24n.). Tento princip spočívá v seřazení různých hláskových změn na různých pozicích na škále percipovaná spisovnost - percipovaná nespisovnost. Tato hierarchie zároveň kondicionuje kombinatoriku jednotlivých tvarů. $\mathrm{V}$ př́padě naší studie je středem pozornosti citlivost posluchače vůči zvukové chybě.

$\mathrm{V}$ následujícím textu řadíme jednotlivé chyby podle jejich percepční závažnosti. Za chyby s nejvyšší mírou percepční závažnosti je považována taková chyba, která byla detekována největším procentuálním podílem respondentů.

Nejčastěji identifikovaná chyba byl tvar [méno], bezprostředně následuje tvar [?ešt'e]. Oba tvary spadají do stejného typu odchylek od ortoepické normy, a to elize iniciálního [i]. Tento typ s $87 \%$ detekce jednoznačně dominuje (srov. tab. 2 i graf 1). Může to být dáno tím, že 
absence iniciálního konsonantu je nejen značně nápadná, ale též působí rušivě při identifikaci výrazu. Může to však také souviset s intenzivně pocit'ovanou vazbou na psanou podobu slova - zřejmě ze stejného důvodu někteří respondenti označují jako chybnou výslovnost tvar slovesa být [sem].

Jako třetí chyba se umístila neortoepická podoba spojení neslabičná předložka + slovo s iniciálním vokálem [vokňe], v němž byl vypuštěn ráz. Česká výslovnostní norma (Hůrková 1995, s. 25) předepisuje bezpodmínečné použití rázu jen ve dvou př́padech: na začátku promluvy tam, kde po pauze následuje iniciální vokál, a právě po neslabičné předložce, následuje-li slovo s iniciálním vokálem. Ovšem jiná chyba téhož typu [vevropje] se v pořadí identifikace umístila až na desátém místě. Tento rozdíl může naznačovat, že artikulační a akustické vlastnosti vokálu mohou ovlivňovat pocit'ovanou potřebu výslovnosti s rázem či bez rázu (středové zadní [o] je artikulačně bližší laryngálnímu rázu než středové přední [e]). Jediný výskyt daného jevu však neumožňuje toto tvrzení ověřit s jistotou, jedná se tedy pouze o náznak možné interpretace.

Na čtvrtém místě v identifikaci výslovnostních chyb se umístil tvar [ňácí], tedy slabičná redukce. Učitelé mohou být na tuto chybu citlivější z důvodu reflexe vlastní mluvní aktivity. V textu se objevuje ještě jeden výskyt chyby stejného typu, a to tvar [?úpe], ten se ale umístil až na 13.-14. místě. Slabičná redukce tvaru [ňácí] se často vyskytuje ve vlastních spontánních projevech učitelů, zatímco tvar [?úpe] je charakteristický spíše pro mluvčí mladšího věku. Percepční závažnost tvarů tedy může souviset $\mathrm{s}$ frekvencí užití daného tvaru ve vlastní mluvní praxi.

Páté místo obsadila identifikace neortoepické spodoby místa artikulace [heščí]. Na to, že se jedná o nedostatek zcela zrrejmý, považujeme její změřenou percepční závažnost za dosti nízkou (méně než polovina respondentů). Šesté v pořadí identifikovatelnosti, a tedy percepční závažnosti, je neortoepické zjednodušení výslovnosti dvou foneticky stejných souhlásek [bezubí]. Až na sedmém místě percepční závažnosti se umístila první chyba týkající se neortoepické výslov- nosti vokálu: jde o zkrácení tvaru [paňi]. Je zajímavé, že nenáležitý tvar [neňi], který spadá do stejného typu výslovnostní chyby, se umístil až na 22.-23. místě. Domníváme se, že stylistický př́źznak tvaru [paňi] je natolik silný, že jej posluchači vnímají intenzivněji než velmi frekventovaný slovesný tvar [neňi]. Následuje zjednodušení souhláskové skupiny v tvaru [?osmnácet] na 8 . místě. Deváté místo v pořadí percepční závažnosti obsadila elize intervokalického konsonantu [poídala], desáté již zmiňovaný druhý př́ípad absence povinného rázu po neslabičné předložce ve spojení [vevropje]. Další odchylky byly detekovány méně než $20 \%$ respondentů, proto je dále nezmiňujeme.

Ani mezi význačnými autoritami oboru nepanuje shoda na ortoepické podobě některých výrazů, což praktickou aplikovatelnost ustanovení ortoepických pravidel češtiny ve školní či jiné profesní praxi, ale i v běžném životě značně komplikuje.

Jako nejobtížněji identifikovatelná se jeví deformace kvality vokálů. Vlivem médií, zejména komerčních, se otevřená výslovnost samohlásek širrí téměř po celém jazykovém území. Tento trend je navíc podpořen menší artikulační náročností otevřené výslovnosti vokálů. Stanovení hranice, do níž je vokál artikulován přiměřeně a za níž už je nepřijatelně otevřený, je značně problematické. Akceptabilita míry otevřenosti vokálů je svázána s individuálními preferencemi hodnotitele, které se odvíjí od jeho regionálního původu, míry lingvistické poučenosti a schopnosti zvukové diskriminace nezávislé na fonologických kategoriích.

Analýzou percepční závažnosti různých realizací výslovnostních odchylek téhož typu zjišt'ujeme značnou nehomogenitu uvnitř jednotlivých kategorií. Nejde zřejmě ani tak o typ výslovnostní chyby, ale spíše o četnost výskytu konkrétního chybného tvaru v běžné každodenní komunikaci, tedy o jakousi podvědomou známost chyby. Při vnímání chyb konstatujeme náznak dvou protichůdných tendencí: chybná výslovnost je tak častá, že si pedagogická veřejnost bud' uvědomuje nutnost ostražitosti (jak je tomu např́klad v případech ztráty iniciálního [j] ve slově [méno], [?ešt'e]), nebo vůči ní jaksi otupěla 
a již ji nevnímá (to je př́ípad, domníváme se, tvarů [neňi], [diš], otevřených vokálů a podobně).

\subsection{Faktory potenciálně ovlivňující schopnost identifikace výslovnostních chyb}

Vzhledem k profesnímu zaměření i regionální diferenciaci respondentů se nabízí otázka, zda profesní př́slušnost k vzdělávacímu stupni (učitelství pro 1. stupeň vs. učitelství pro 2. a 3. stupeň) nebo regionální př́slušnost jsou faktory, které se podílejí na schopnosti respondentů identifikovat jednotlivé výslovnostní chyby, eventuálně ovlivňují citlivost vuči určitému typu chyby. Jinými slovy zjištujeme, zda jsou rozdíly mezi skupinami náhodné, nebo zda jsou vázány na některé kvantifikovatelné faktory. Realita mluveného jazyka je totiž místně, sociálně i generačně proměnlivá (Krčmová 2009, s. 12).

Ke zjištění relevance takových faktorů přispívá statistická analýza výsledků percepčních testů. Tentokrát je ovšem nutno seskupit výsledky podle dvou kritérí:

a) profesní př́slušnost k vzdělávacímu stupni,

b) region působiště.

Tyto údaje jsme v dotaznících též sledovali a získaná data jsme ve fázi analýzy podle nich rozdělili.

\subsubsection{Diferenciace výsledků podle profesní př́íslušnosti k vzdělávacímu stupni}

V tabulce číslo 3 uvádíme průměrné výsledky míry identifikace chyb seřazené podle vzdělávacího stupně, na kterém respondenti působí. Výsledky byly získány součtem počtu identifikovaných výslovnostních chyb u každého respondenta a zprůměrováním těchto hodnot. V řádcích jsou jednotlivé vzdělávací stupně, sloupec $\mathrm{N}$ uvádí počet respondentů pro každý z těchto stupňů. Jsou uvedeny výsledky dosažené při prvním poslechu (bez opory) a při druhém poslechu, při němž měli respondenti $\mathrm{k}$ dispozici přepis textu ( $s$ oporou). Údaj o smě- rodatné odchylce naznačuje, do jaké míry jsou výsledky jednotlivých respondentů srovnatelné: čím nižší směrodatná odchylka, tím koherentnější (tj. podobnější) výsledky v rámci skupiny jsou.

Tab. 3. Průměry a směrodatné odchylky identifikace výslovnostních chyb podle vzdělávacího stupně, na kterém respondenti působí

\begin{tabular}{|c|c|c|c|c|c||}
\hline \multirow{2}{*}{ Stupeň } & \multirow{2}{*}{$\mathbf{N}$} & \multicolumn{2}{|c|}{ Bez opory } & \multicolumn{2}{c|}{ S oporou } \\
\cline { 3 - 6 } & & průmĕr & sm. odch. & průměr & sm. odch. \\
\hline 1. & 56 & 5,8 & 2,4 & 7,7 & 2,7 \\
\hline 2. & 66 & 6,9 & 2,2 & 9,3 & 2,7 \\
\hline 3. & 26 & 6,7 & 2,2 & 9,4 & 1,7 \\
\hline $\begin{array}{c}\text { Všichni } \\
\text { respondenti }\end{array}$ & $\mathbf{1 4 8}$ & $\mathbf{6 , 5}$ & $\mathbf{2 , 3}$ & $\mathbf{8 , 7}$ & $\mathbf{2 , 7}$ \\
\hline
\end{tabular}

Je patrné, že výsledky respondentů působících na 2. a 3. stupni školy jsou jednak nepatrně koherentnější (směrodatná odchylka je nižší), jednak vzhledem $\mathrm{k}$ absolutním počtům správně identifikovaných chyb znatelně lepší. Srovnatelnost výsledků všech tř́ skupin přináší statistický test jednorozměrné analýzy rozptylu ANOVA. Srovnávali jsme vzájemně výsledky skupin učitelů $1 ., 2$. a 3 . stupně, a to jak bez opory, tak s oporou psaného textu. Byla testována nulová hypotéza, tedy že rozdíly mezi skupinami nejsou statisticky relevantní. Aby byla tato hypotéza potvrzena, musela by dosažená hladina významnosti testu být vyšší než 0,05 . Tam, kde hodnota klesá pod 0,05 , je hypotéza nepotvrzena. Dosažená hladina významnosti $\mathrm{v}$ testu ANOVA je při porovnání výsledků identifikace chyb učiteli různých stupňů 0,030 , resp. 0,002 pro poslech bez opory/s oporou psaného textu; můžeme tedy s určitou rezervou ${ }^{8}$ konstatovat rozdíl mezi skupinami respondentů-učitelů na prvním a respondentů-učitelů na druhém stupni. Při poslechu s oporou psaného textu se rozdíly mezi učiteli na 1. a 2., resp. na 1. a 3. vzdělávacím stupni ukázaly jako statisticky vý-

\footnotetext{
${ }^{8}$ Vzorek respondentů je málo početný vzhledem k málo významným rozdílům ve výsledcích.
} 
znamné (srov. tab. 4). Výsledky percepčních testů učitelů různých stupňů tedy ukazují, že percepční významnost ortoepických chyb, resp. schopnost učitele identifikovat ortoepickou chybu, souvisí s vzdělávacím stupněm, na němž respondent působí (a pro nějž, jak lze ve většině případů předpokládat, byl připravován).

Pro detailnější analýzu jsme přikročili k t-testům, které srovnávají vždy dvojici skupin. Výsledky t-testů pro porovnání jednotlivých skupin respondentů podle toho, na jakém stupni školy působí, jsou shrnuty $\mathrm{v}$ tabulce 4

Tab. 4. Výsledky t-testů pro skupiny respondentů - učitelů 1., 2. a 3 . vzdělávacího stupně

\begin{tabular}{||c|c|c||}
\hline \multirow{3}{*}{ Bez opory } & Srovnávané stupně & $\begin{array}{c}\text { Hladina významnosti } \\
\text { t-testu pro srovnání skupin }\end{array}$ \\
\cline { 2 - 3 } & $1 . \times 2$. & 0,012 \\
\cline { 2 - 3 } & $1 . \times 3$. & 0,101 \\
\hline \multirow{3}{*}{ S oporou } & $2 . \times 3$. & 0,689 \\
\cline { 2 - 3 } & $1 . \times 2$. & 0,002 \\
\cline { 2 - 3 } & $1 . \times 3$. & 0,001 \\
\hline
\end{tabular}

Z uvedených dat vyplývá, že výsledky skupin respondentů-učitelů na 2. a 3. stupni - jsou srovnatelné (sig. >0,05), zatímco rozdíly mezi výsledky respondentů-učitelů na 1 . stupni a zbývajícími dvěma stupni jsou statisticky závažné, a to v prípadě poslechu bez opory psaného textu i s jeho oporou. Můžeme tedy konstatovat, že výsledky percepčních testů zjišt'ujících schopnost detekovat výslovnostní chyby v mluveném projevu jsou významně jiné, nižší (viz tab. 3), u učitelů prvního stupně.

Toto zjištění je alarmující ve světle skutečnosti, že je to právě učitel primárního vzdělávání, který je prvním uvědomělým a systematickým řečovým vzorem pro dítě. Navíc správná výslovnost učitele má významnou didaktickou roli, nebot' je důležitá pro rozvoj ortografické kompetence (srov. Babušová 2014). Přitom spojení fonetické a orto- grafické složky řeči je na 1. stupni stěžejní téma. Řečové kvality učitele 1. stupně i jeho schopnost zaznamenat chybu v mluveném projevu mají nenahraditelný vliv na další rozvoj, spontánní či uvědomělý, kultury mluveného projevu dítěte.

\subsubsection{Diferenciace výsledků podle regionu působiště}

Jak již bylo uvedeno, percepční testy byly zadávány v Praze, Brně a Olomouci. Součástí krátkého anonymního dotazníku byl i údaj o regionu působiště respondenta. Tento údaj jsme do dotazníků zařadili proto, abychom ověřili hypotézu, že regionální diferenciace respondentů bude mít vliv na míru vnímavosti některých typů výslovnostních chyb v Praze na jedné straně a v Brně a v Olomouci na straně druhé. Drtivá většina účastníků setkání v Praze označila jako region působiště místo v Čechách, do Brna přijeli účastníci především z jižní a východní Moravy a setkání v Olomouci se zúčastnili drtivou většinou učitelé z východní, střední a severní Moravy a ze Slezska. Nebylo by překvapivé, kdyby respondenti z Čech (setkání konaná v Praze) reagovali citlivěji, tedy ve větší četnosti identifikace, na vypuštění povinného rázu ve spojeních [vevropje] a [vokňe], zatímco u moravských a slezských respondentů jsme očekávali vyšší procento identifikace otevřených vokálů např. ve výrazech [film], [l1dovíx], [s1], [b1l1], [slečn1], [spívalı] a [b1lo]. Komparaci četnosti identifikace výslovnostní chyby v uvedených výrazech, které se jakožto charakteristické pro regionálně příznakovou mluvu pro srovnání nabízejí, ukazuje tabulka 5. Je třeba poznamenat, že byla testována pouze rozdílnost v regionu působiště, to znamená, že následující výsledky platí bez rozlišení vzdělávacího stupně, na němž respondent působí.

$\mathrm{Z}$ procentuálního hodnocení nelze vysledovat tendenci, která by podpořila naši domněnku, že respondenti z Moravy a Slezska budou cit-

${ }^{9}$ Ačkoliv považujeme respondenty ze setkání konaných v Brně a Olomouci za jeden celek, ponecháváme údaje $\mathrm{v}$ tabulce rozdělené, aby ještě více vynikl závěr, že region působišstě neovlivňuje významně míru vnímavosti vůči výslovnostním chybám charakteristickým pro druhý region. 
livější na otevřené vokály a budou je tedy identifikovat jako chybnou výslovnost. Tendence respondentů z Čech identifikovat chybu, která se v mluvním úzu jejich okolí běžně nevyskytuje, tedy vypuštění povinného rázu po neslabičné předložce, s vyšší frekvencí, než tak činili moravští a slezští respondenti, se potvrdila pouze $\mathrm{v}$ jednom př́padě ze dvou ([vevropje]).

Tab. 5. Identifikace chyby ve vybraných výrazech v Praze, Brně a Olomouci ${ }^{9}$

\begin{tabular}{|c|c|c|c|}
\hline & Praha & Brno & Olomouc \\
\hline [film] & $3 \%$ & $4 \%$ & $6 \%$ \\
\hline [lidovíx] & $6 \%$ & $4 \%$ & $6 \%$ \\
\hline$[\mathrm{s} 1]$ & $0 \%$ & $0 \%$ & $0 \%$ \\
\hline [bill] & $0 \%$ & $0 \%$ & $6 \%$ \\
\hline [slečnı] & $0 \%$ & $0 \%$ & $0 \%$ \\
\hline [spívalı] & $0 \%$ & $0 \%$ & $0 \%$ \\
\hline [bilo] & $0 \%$ & $0 \%$ & $0 \%$ \\
\hline [vevropje] & $23 \%$ & $17 \%$ & $13 \%$ \\
\hline [vokňe] & $53 \%$ & $65 \%$ & $57 \%$ \\
\hline
\end{tabular}

Vzhledem k nízké četnosti výskytu identifikace chyby ve sledovaných jevech považujeme výsledky statistické analýzy za nevýznamné a uvedenou hypotézu za nepotvrzenou.

\section{Nejčastěji identifikované chyby učiteli vs. nejčastější chyby v projevech žáků}

V nedávné studii jsme se zabývali četností různých typů výslovnostních chyb v projevech žáků 1. ročníku gymnázia (Vlčková-Mejvaldová, Štěpáník 2017-2018). Pořadí četnosti výskytu jednotlivých typů výslovnostních chyb (Babušová 2014, s. 117) ve spontánních projevech žáků je vyjádřeno v prvním sloupci tabulky 6 . V jejím druhém sloupci jsou seřazeny kategorie chyb, jak byly percipovány respondenty během percepčních testů v rámci této studie.
Tab. 6. Pořadí četnosti výskytu výslovnostních chyb v mluvených projevech žáků a pořadí jejich percepční závažnosti u učitelů

\begin{tabular}{||l|l||}
\hline $\begin{array}{c}\text { Pořadí četnosti výskytu y autentických } \\
\text { projevech žákú 1. ročniku gymnázia } \\
\text { (Vlčková-Mejvaldová, SStěpáník 2017-2018) }\end{array}$ & $\begin{array}{c}\text { Pořadí dle percepční závažnosti } \\
\text { (aktuální studie) }\end{array}$ \\
\hline 1. Zjednodušení souhláskových skupin & 1. Elize iniciálního [j] \\
\hline 2. Redukce vokálů & 2. Absence povinného rázu \\
\hline 3. Otevřené vokály & 3. Chybná asimilace místa artikulace \\
\hline 4. Zkracování vokálů & 4. Slabičná redukce \\
\hline 5. Elize intervokalického konsonantu & $\begin{array}{c}\text { 5. Zjednodušení výslovnosti dvou stejných } \\
\text { souhlásek }\end{array}$ \\
\hline 6. Slabičná redukce & 6. Elize intervokalického konsonantu \\
\hline 7. Prodloužení krátkých vokálů & 7. Zkracování vokálů \\
\hline 8. Elize iniciálního [j] & 8. Disimilace způsobu artikulace \\
\hline 9. Zjednodušení výslovnosti dvou stejných \\
souhlásek & 9. Zjednodušení souhláskových skupin \\
\hline 10. Chybná asimilace místa artikulace & 10. Redukce vokálů \\
\hline 11. Chybná asimilace zpo̊sobu artikulace & 11. Otevřné vokály \\
\hline 12. Chybná znělost & \\
\hline
\end{tabular}

Z tabulky je zřejmé, že mezi umístěním v pořadí četnosti toho kterého typu výslovnostní chyby a jeho percepční závažností panuje nepř́má úměra: takové srovnání by mohlo nasvědčovat tomu, že čím menší senzibilitu učitelé projevují vůči konkrétnímu typu výslovnostní chyby, tím častěji se tento typ chyby objevuje v mluvených projevech žáků. Takový výsledek naznačuje př́imý vliv učitelovy ne/kompetence na kvalitu žákova mluveného projevu.

\section{Diskuze limitů výzkumu}

Předložená studie má určité limity, které zde nabízíme k diskuzi. Získat zvukový materiál vhodný pro výuku ortoepie, natož pak pro výzkum percepční závažnosti ortoepických chyb je, jak víme z vlastní 
praxe, úkol značně náročný (mj. o tom svědčí takřka úplná absence učebnic, $\mathrm{k}$ nimž by byly připojeny nahrávky a jež by si kladly za cíl rozvoj ortoepické kompetence uživatelů). Jsme si proto vědomi toho, že zvukový materiál použitý pro výzkum může být zpochybňován pro svou absenci autentičnosti, přirozenosti, realističnosti apod. Lze namítat, že nahrávka obsahuje otevřené vokály, které jsou nejčastěji přisuzovány středočeským mluvčím, a zároveň absenci povinného rázu, jenž je charakteristický pro východní část českého jazykového území. Jeden autentický mluvený komunikát, který by obsahoval výslovnostní chyby charakteristické pro různé územní celky, by se však objevil jen stěží (jeho existenci pochopitelně nemůžeme vyloučit). Nechtěli jsme respondenty zatížit př́liš dlouhou nahrávkou, nebo dokonce několika nahrávkami a zároveň pro účel výzkumu bylo nutné postihnout co nejširší škálu výslovnostních chyb. Před použitím ve výzkumu jsme nahrávku pilotovali na vzorku dospělých mluvčích češtiny a rovněž jsme ji vyzkoušeli v jedné třídě čtyřletého gymnázia. Výsledky pilotního ověření ukázaly, že materiál je pro identifikaci ortoepických chyb zcela funkční. Mluvčí, která nahrávku namluvila, vystudovala DAMU a studovala u J. Hůrkové, byla schopná výborně napodobit autentický projev a ortoepické chyby do něj přirozeně zakomponovat. Aby se učitelé mohli věnovat chybám pouze na rovině zvukové, bylo třeba potlačit nespisovnost na jiných rovinách, jinak by si respondenti přirozeně všímali primárně nespisovnosti na rovině morfologické (vlastní pedagogická zkušenost autorů). Z tohoto důvodu byla použita nahrávka, v níž jsou chyby provedeny záměrně a kontrolovaně, nikoli nahrávka autentické promluvy.

Jsme si též vědomi toho, že údaje uvedené v kapitole 6 neprokazují směr kauzálního působení a že vzorky použité v obou studiích jsou velmi omezené. Vnímáme však tuto část jako usouvztažnění dvou výzkumů, které by mohlo naznačovat určitou tendenci. Nicméně zároveň jasně upozorňujeme, že by bylo třeba dalšího extenzivního zkoumání, aby mohla být naznačená souvislost mezi kompetencí žáků a kompetencí učitelů prokazatelně potvrzena.
Jako limit výzkumu se též nabízí určení regionální příslušnosti respondentů. Vycházíme z údaje, kde učitel pedagogicky působí. Samozrrejmě se však nabízí, že jeho ortoepická kompetence je ovlivněna regionem jeho původu. Nebylo však v našich možnostech takové údaje zjišt'ovat.

\section{Diskuze}

Prostřednictvím percepčních testů jsme zjišt'ovali, do jaké míry jsou učitelé různých vzdělávacích stupňů a z různých regionů schopni identifikovat výslovnostní chyby (tedy odchylky od ortoepické normy) v mluveném projevu. Výsledky našeho výzkumu naznačují, že v percepční závažnosti nehraje roli jen typ chyby, ale možná též frekvence konkrétního defektního tvaru v mluvené komunikaci. Některé tvary byly jako chybné rozpoznány vysokým počtem respondenti̊ ([méno], [?ešt'e]), jiné typy chyb jsou pro učitele rozpoznatelné jen obtížně (např. [prəst'e]). Na druhou stranu vysoká frekvence výskytu určitého typu chyby může vést $\mathrm{k}$ tomu, že se citlivost mluvčích vůči ní oslabí natolik, že ji jako defektní přestanou vnímat (např. [diš]).

Na základě našich dat lze jako okolnosti, které ovlivňují percepční závažnost výslovnostní chyby, označit:

1) frekvenci výskytu chyby v komunikaci obecně či ve vlastních projevech. Vysoká frekvence výskytu určité chyby může vést k zvýšení citlivosti vůči ní, anebo naopak k netečnosti, kdy si jí posluchač přestává všímat. Tento faktor tedy může působit i protikladně;

2) sledování didaktických cílů (tzv. „didaktická výslovnost”). Napřr. při diktátu učitelé pečlivě až přehnaně artikulují, čímž se nevědomě mohou dopouštět výslovnostní chyby na úrovni hyperkorektnosti (např. výslovnost iniciálního [j] ve tvarech slovesa být; k hyperkorektnosti ve školském pojetí srov. též Svobodová 2003, s. 56) a postupně tuto výslovnost přestanou vnímat jako chybnou.

Přestože byli respondenti dotazováni pouze na chyby na rovině zvukové, 23 \% z nich označilo jako defektní slovo nepamatuju. Tento 
tvar je sice hovorový, avšak spisovný; navíc jde o variantnost na rovině morfologické, o výslovnostní chybu se zde nejedná. Šest respondentů označilo jako chybné použité lexikum chlapi, protože jej považovali za neadekvátní z hlediska stylistického. Tyto výsledky nasvědčují tomu, že někteří učitelé v praxi mohou mít problém odlišit rovinu zvukovou od ostatních jazykových rovin.

Celkem 17 respondentů označilo za chybnou výslovnost slovesného tvaru [sem] tam, kde byl užit jako součást minulého času. V tomto případě norma připouští redukovanou variantu jako plnohodnotnou, plnou výslovnost [jsem] označuje v některých př́ípadech za hyperkorektní (Hůrková 1995, s. 34). Ojediněle se rovněž objevilo označení tvaru [kultura] jako chybné. Domněle jediná správná výslovnost [kultúra] se objevuje jako jediná ortoepicky vyhovující možnost ve Slovníku spisovného jazyka českého (1989), Hůrková (1995, s. 52) ale připouští jako rovnocenné obě možnosti, tedy [kultura] i [kultúra]. Tyto výsledky dále nasvědčují tomu, že povědomí o aktuálních ustanoveních ortoepické normy je mezi učiteli spíše malé.

Významné rozdíly mezi jednotlivými regiony (Praha, Brno, Olomouc) zjištěny nebyly. Toto konstatování bylo poměrně prediktabilní: roli hraje migrace respondentů mezi regionem původu, regionem studia a regionem stávajícího působiště a samozřejmě celkové stírání rozdílů ve zvukových vlastnostech oblastních variant mluvené češtiny.

Oproti tomu byly zjištěny rozdíly ve výsledcích percepčních testů u respondentů působících na různých vzdělávacích stupních. Výsledky hovoří v neprospěch učitelů 1. stupně, což je zjištění alarmující vzhledem ke kruciálnímu vlivu učitelů primárního vzdělávání na žáky, mj. i v oblasti kultury mluveného projevu.

Za zajímavé pak považujeme zjištění, k němuž jsme došli srovnáním výsledků stávající studie s výsledky studie předchozí a které naznačuje tendenci k souvislosti mezi schopností učitele identifikovat (a potenciálně opravit) výslovnostní chybu a typem výslovnostních chyb, které se objevují v mluvených projevech žáků.
Není v možnostech našeho výzkumu zjistit příčiny nízké úrovně schopnosti diskriminace výslovnostních chyb, teoretické průpravy se však budoucím učitelům dostává (srov. výše). Můžeme se ovšem domnívat, že příčina nízké kompetence učitelů v oblasti ortoepie je několikerá:

- Umístění studijních předmětů, které se zvukovými vlastnostmi řeči včetně ortoepie zabývají, na začátek studia, může být problematické. Důvody, proč se zvuková stránka jazyka objevuje hned na počátku studia, jsou zřejmé: fonetika a fonologie jako základní disciplíny vztahující se ke všem dalším rovinám jsou zásadní pro pochopení celkového fungování jazykového systému. Pokud se ale na nabyté vědomosti v následujících kurzech dále nenavazuje, hrozí riziko, že při nástupu do praxe již učitelé ortoepické zásady a způsob odhalování výslovnostních chyb v paměti nemají.

- Obsah předmětů zaměřujících se na zvukovou stránku jazyka je v programech vzdělávajících budoucí učitele českého jazyka koncipován spíše teoreticky, oborově, chybí praktické a didaktické využití poznatků.

- Zvuková stránka jazyka patří mezi nejvíce opomíjené jazykové roviny ve výuce - jak potvrzují Vlčková-Mejvaldová, Sojka (2016) nebo Balkó (2012-2013), absolventi středních škol se s ortoepiî mnohdy setkávají až na vysoké škole.

- Příčinou může být též obecná rezignace na kvalitu mluveného projevu a otupělost vưči výslovnostním chybám - a to i v řeči profesionálních mluvčích. Palková (2017-2018, s. 212) konstatuje souvislost pokleslého stavu řeči ve veřejných projevech se stavem současné sociokulturní atmosféry.

\section{Závěr}

Cílem naší studie bylo zjistit, do jaké míry jsou učitelé na různých stupních škol schopni identifikovat výslovnostní chyby a jaké faktory mohou tuto jejich schopnost ovlivňovat. Výsledky našeho výzkumu 
naznačují, že znalost ortoepické normy a schopnost postihnout výslovnostní chyby v prrirozeném mluveném projevu je u učitelů poměrně nízká. Statistické prostředky srovnání výsledků skupin, rozdělených podle kritéria vzdělávacího stupně, na němž respondent působí, ukazují, že nejnižší je u učitelů 1. stupně ZŠ. Tato skutečnost se zdá být pro další péči o kulturu mluveného projevu závažná, nebot' právě na 1. stupni mohou být děti nejefektivněji vědomě a cíleně vedeny, potažmo vzdělávány, i v oblasti řečové kultury, a je to právě 1 . stupeň ZŠS, kdy se utvářejí základní formalizované mluvní návyky. Vzhledem k tomu, že se rok od roku v ČR zvyšuje počet osob s problémy řeči (viz výše) je posílení znalostí o zvukové stránce u učitelů (nejen) 1. stupně př́mo nutné.

Malé a omezené povědomí o ortoepické normě a znalosti fonetiky a fonologie mezi učiteli nutně musí komplikovat také zprostředkování tohoto učiva ve školách a poskytování zpětné vazby žákům $\mathrm{k}$ jejich mluveným projevům (srov. Vlčková-Mejvaldová, Štěpáník 2017 -2018). Jak naše studie naznačila, může existovat korelace mezi chybami v mluvených projevech žáků a schopností učitelů určité typy chyb detekovat. Že mezi znalostmi a dovednostmi učitele a znalostmi a dovednostmi žáka je př́mý vztah, potvrdily mnohé jiné výzkumy (srov. Vašutová 2007; Čechová 1998), avšak pro oblast mluveného projevu by bylo potřeba takový závěr dále ověřit.

Jak jsme konstatovali v jiné naší studii, situaci komplikuje fakt, že učitelé připisují zvukové stránce jazyka velmi malou důležitost (Vlčková-Mejvaldová, Štěpáník 2017-2018), přestože její význam pro každodenní komunikaci kteréhokoliv mluvčího je naprosto zásadní. Zdá se, že stále v české škole přetrvává přeceňování jiných jazykových rovin ve výuce (především morfologie a syntaxe) a uznávání především kodifikace psané (tedy pravidel pravopisu) oproti kodifikaci mluvené (tedy ortoepické normy) - srov. k tomu též Svobodová (2003) nebo Kraus (1996-1997), a tedy i nedostatečnou úroveň mluvených projevů absolventů škol (srov. Balkó 2005-2006). Jednostranná výuka pravopisu a silná orientace na psanou podobu jazyka dokonce mohou mít za následek likvidaci „intuitivní schopnosti diskrimina- ce reálných zvukových segmentů řeči” (Vlčková-Mejvaldová, Sojka 2016, s. 52).

Z naší studie vyplývá potřeba posílit povědomí o ortoepické normě a zvukové stránce obecně nejen ve školách, ale rovněž ve vzdělávání učitelů. Domníváme se, že jedině takovým způsobem budeme moci dosáhnout potlačení výskytu nežádoucích mimojazykových informací v mluveném projevu a kultivovat mluvenou češtinu jakožto primární a nejpřirozenější komunikační prostředek.

\section{Literatura}

B a b u š o vá G., 2014, Evoluce komunikačnich činností v teorii a praxi. Praha: PedF UK.

B a 1 k ó I., 2005-2006, Stav zvukové stránky mluvených projevů absolventů SŠ a př́činy zjištěných nedostatki̊, „Český jazyk a literatura” 56, s. 15-21.

B a 1 k ó I., 2007-2008, Pauzy v mluveném projevu učitele, „Český jazyk a literatura” 58 , s. $17-21$

B a l k ó I., 2012-2013,Nepodceňuji učitelé zvukovou stránku jazyka?, „Český jazyk a literatura" 63, s. 6-12.

B o ř e k - D o h a l s k á M. a kol., 2016, Závěr. In Fonetika a fonologie v př́pravném vzděláváni učitelù. Filologické studie. Praha: Karolinum, s. 154-158.

B r a b c o v á R. a kol., 1990, Didaktika českého jazyka pro studujíci oboru učitelství na prvním stupni základní školy. Praha: Státní pedagogické nakladatelství.

B r o w n e A., 2007, Teaching and learning communication, language and literacy. London: Paul Chapman.

Č e c h ová M., 1985, Vyučování slohu. Praha: SPN.

Č e c h ov á M., 1998, Komunikační a slohová výchova. Praha: ISV nakladatelství.

Č e c hová M., S t y blík V., 1998, Čeština a její vyučování: didaktika českého jazyka pro učitele základnich a střednich škol a studenty učitelství. Praha: SPN.

Č e j k a M., 2013, Čtyři menši spisy. Brno: Host.

Č e r m á k P., 2015, Fonetika a fonologie současné španělštiny. Praha: Karolinum.

Č m e j r k o vá S., H o f f m a n n o vá J., 2011, Mluvená čeština: hledání funkčního rozpétí. Praha: Academia.

D a n e š F., 2009, Kultura a struktura českého jazyka. Praha: Karolinum.

D v or á č k o vá V., 2014, K činnosti komisi fonografické, ortoepické a fonetické České akademie věd a umění, „Práce z dějin Akademie věd” 6, č. 1, s. 47-60.

H áj k o vá E., 2011, Rétorika pro pedagogy. Praha: Grada. 
H ál a B., 1967, Výslovnost spisovné češtiny I: Zásady a pravidla. Výslovnost slov českých. Praha: Academia.

H o ff $\mathrm{m}$ a n n o vá J. a kol., 2016, Stylistika mluvené a psané češtiny. Praha: Academia.

H r o n e k J., 1972, Obecná čeština. Praha: Univerzita Karlova.

H ůr k o vá J.,1995, Česká výslovnostni norma. Praha: Scientia.

J a ní k T., 2009, K možnostem rozvijení učitelových didaktických znalostí obsahu. In T. Janík a kol., Možnosti rozvíjení didaktických znalostí obsahu u budoucích učitelì. Brno: Paido, s. 9-16.

K r a u s J., 1996-1997, Několik úvah o úloze rétoriky ve škole, „Český jazyk a literatura" 47, s. 193-199.

K r a u s J., 2010, Rétorika a řečová kultura. Praha: Karolinum.

K r č m o v á M., 2009, Fonetika a fonologie. Brno: Masarykova univerzita. On-line: https://is.muni.cz/do/1499/el/estud/ff/ps09/fonetika/tisk_2009/Fonetika_a fonologie_logo.pdf. [cit. 14.7.2018].

K rč m o vá M., 2012-2018, Transkripce. In Nový encyklopedický slovnik češtiny online. On-line https://www.czechency.org/slovnik/TRANSKRIPCE\#fone tická transkripce [cit. 14.6.20 18].

K ro botová M., 2000, Spisovná výslovnost a kultura mluveného projevu. Olomouc: Univerzita Palackého.

K u č e r a H., 1955, Phonemic variations of spoken Czech, „Slavic Word” 11, s. 575 -602 .

K u 1 d a n o vá P., 2001, Krize mluvních vzorů v Čechách?, „Čeština doma a ve světě", s. 156-161.

L o11ok M., 2018, Několik poznámek k nelformálnosti jazykové komunikace $v$ češtinè,, Bohemistyka", s. 5-18.

Ma c o u n T., D v ořá k o vá Š., 2008, Metafora v mluvených projevech moderátorů dvou rozhlasových stanic. In L. Kralčák (ed.), Hovorená podoba jazyka $v$ médiách. Nitra: Univerzita Konštantína Filozofa. s. 145-153.

Málko vá J., 2012, Mluvený projev učitele ve výukové komunikaci na 2. stupni základní školy. Dizertační práce. Plzeň: FPE ZČU.

Málk o vá J., 2014-2015, Kultivovanost mluveného projevu učitele, „Český jazyk a literatura" 65 , s. $105-109$

M a r e š J., K ř i v o h 1 a v ý J., 1995, Komunikace ve škole. Praha: SPN.

M a r e š J. a kol., 1996, Učitelovo pojetí výuky. Brno: Masarykova univerzita, Centrum pro další vzdělávání učitelů.

P a 1 k o vá Z., 1994, Fonetika a fonologie češtiny. Praha: Karolinum.

P a 1 k o vá Z., 2005, Zvuková podoba veřejných mluvených projev z hlediska jazykové kultury, „Čeština doma a ve světě”, s. 37-38.
P a 1 k o v á Z., 2008-2009, Výslovnost současné češtiny a kultura řeči, „Český jazyk a literatura" 59, s. 18-26.

P a 1 k o v á Z., 2017-2018, Řeč mateřská, řč bohatá, „Český jazyk a literatura” 68 , s. 209-215.

Píš o vá I. a kol., 2013, Učitel expert: jeho charakteristiky a determinanty profesního rozvoje (na pozadi výuky cizich jazyků). Brno: Masarykova univerzita.

Podla hová L., 2004, První kroky učitele. Praha: Triton.

P r ů ch a J., 2011, Dětská reč a komunikace. Poznatky vývojové psycholingvistiky. Praha: Grada.

R o m p o r 11 M. a kol., 1978, Výslovnost spisovné češtiny. Výslovnost slov přejatých Výslovnostni slovnik. Praha: Academia.

Slovník spisovného jazyka českého, 1989. Praha: Academia.

S u c h á n k o vá O., 1992, K výslovnosti slova konsensus, „Naše řeč” 75, s. 223-224.

S v o b o d o vá J., 2003, Jazyková specifika školské komunikace a výuka mateřštiny. Ostrava: Ostravská univerzita.

Š i m o n í k O., 1994, Začinající učitel: Některé pedagogické problémy začínajicích učitelü. Brno: Masarykova univerzita.

Š m a j s ová B u c h tová B., 2005, Cvičné texty z rétoriky. Brno: Masarykova univerzita.

Š mej k a lová M., 2010, Čeština a škola - úryvky skrytých dějin. Praha: Karolinum.

Š m i 1 a u e r V., 1968-1969, Profil češtináře, „Český jazyk a literatura” 19, s. 241-249.

Štěpáník S., V lčková-M e jvaldová J., 2018, Cvičebnice výslovnosti češtiny nejen pro školni výuku. Plzeň: Fraus.

Š tě páník S., V l čková-M ejvald ová J., 2019, Impact of Teachers' Beliefs on Teaching Phonetic Aspects: the Case of Czech as L1, v tisku.

Š t ě p á n o vá V., 2013, Fonetická problematika v jazykové poradně, „Naše řeč” 96 , s. 61-77.

Š v aří č e k R., Š e d'o vá K., Š a l a m o u n o vá Z., 2012, Komunikace ve školni třidě. Praha: Portál.

ÚZIS, 2014, Činnost logopedických pracovišt $t^{\prime} v \check{C} R$ v roce 2013. Praha: ÚZIS.

V a š u to vá J., 2007, Být učitelem: co by mél učitel vědět o své profesi. Praha: PedF UK.

V l č k o vá - M e j v a l d o vá J., 2019, Dobrodružství fonografického archivu, v tis-

V lčková-M ejvaldová J., S ojka P., 2016, Fonetika a fonologie českého jazyka. In Fonetika a fonologie v prípravném vzděláváni učitelù. Filologické studie. Praha: Karolinum, s. 37-67.

Vlčková-M ejvaldová J., Št ěpáník S., 2017-2018, Jak na zvukovou stránku ve výuce češtiny?, „Český jazyk a literatura” 68, s. 112-125. 